\title{
Genetic Parameters of Economic and Fibre Characters in Upland Cotton (Gossypium hirsutum L.)
}

\author{
J. Pandiyan ${ }^{1 *}$, A. Ramalingam ${ }^{2}$, M. Arumugam Pillai ${ }^{1}$ and S. Saravanan ${ }^{1}$ \\ ${ }^{1}$ Department of plant breeding and genetics, Agricultural College and Research Institute \\ Killikulam, Tuticorin-628 252, Tamilnadu, India \\ ${ }^{2}$ Agricultural Research Station, Kovilpatti, TNAU-628 501, Tamilnadu, India
}

*Corresponding author

\section{Keywords}

Cotton, GCV, PCV, Heritability, Genetic advance at percent mean

Article Info

Accepted:

15 May 2019

Available Online:

10 June 2019

\section{A B S T R A C T}

The present investigation was performed with fifty-three genotypes of Gossypium hirsutum L. cotton to get information on genetic variability, heritability and genetic advance as per cent of mean for yield, yield supporting and fibre quality attributes. The value of PCV was higher than GCV which explains that instead of genotypic component, the environmental component also influences in the expression of the character. The characters like number of bolls per plant, number of flower bearing nodes and seed cotton yield recorded higher values of GCV and PCV. Moderate values of GCV and PCV was observed for plant height, number of sympodia, length of internode, boll weight, seed index, lint index, ginning out turn and micronaire value. Length of sympodia resulted in moderate GCV and higher PCV. Lower values of GCV and PCV was observed for days to first flowering, days to fifty per cent flowering, days to first boll bursting, days to fifty per cent boll bursting, upper half mean length, uniformity index, fibre strength and elongation per centage. Higher heritability with higher genetic advance as per cent of mean was recorded by plant height, number of flower bearing nodes, boll weight and lint index. This suggests that these characters could be improved by simple selection because they are controlled by additive gene action. Number of sympodia, number of bolls per plant, seed cotton yield, length of internode and length of sympodia recorded moderate heritability and higher genetic advance which may be due to non-additive gene acion. Similarly moderate heritability and low genetic advance as per cent of mean was observed for uniformity index and elongation per centage and high heritability with moderate genetic advance as per cent of mean for days to first flowering, days to fifty per cent flowering, days to first boll bursting, days to fifty per cent boll bursting, upper half mean length, ginning out turn and seed index were due to non-additive gene action. Hence these traits will be improved through heterosis breeding or selection may be postponed to later generation.

\section{Introduction}

Cotton popularly known as 'king of fibre', for its value on Indian economy and textile industries. Synthetic fibres like linen, nylon have dominated the cotton production in the past decade. Now the attention of people has diverted towards the use of natural fibre, especially cotton due to their positive impacts on the environment (Lokeshkumar et al., 
2018). For any crop improvement, the variability is a requisite one. Knowledge on the extent of variability exists in an experimental material helps to formulate successful breeding programme. The computation of co-efficient of variation reveals only the extent of variation in the experimental material but not reveals the heritable portion of the character from one generation to next generation. Hence the estimation of heritability and genetic advance is become necessary, because both these parameters explain the heritable portion of variation from one generation to next generation.

Considering the above information, the present investigation was carried out among 53 upland cotton genotypes on variability, heritability and genetic advance as per cent of mean of yield, yield attributing traits and fibre quality characters.

\section{Materials and Methods}

The present study was undertaken at the Department of Plant Breeding and Genetics, AC\&RI, Killikulam with 53 genotypes of Gossypium hirsutum L. during summer 2018. The trial was laid out in Randomized Block Design with three replications. The seeds were sown on a $6 \mathrm{~m}$ length row followed $75 \times 30 \mathrm{~cm}^{2}$ spacing. Agronomic management practices were followed as per the recommendations.

Twenty quantitative and fibre quality traits were studied among the experimental population. The traits includes Plant height, number of sympodia per plant, number of bolls per plant, number of flower bearing nodes, length of internode, length of sympodia, boll weight, days to first flowering, days to fifty per cent flowering, days to first boll bursting, days to fifty per cent boll bursting, seed index, lint index, ginning out turn, upper half mean length, uniformity ratio, fibre strength, elongation percentage, micronaire value and seed cotton yield per plant.

The Analysis of Variance was worked out to decipher the difference among genotypes for the characters under study as given by Panse and Sukhatme (1967). The phenotypic and genotypic variances were estimated by the formulae given by Lush (1940). The phenotypic and genotypic co-efficient of variations were computed by adopting the formulae given by Burton (1952). Heritability was calculated by formulae given by Lush (1940). Genetic advance was calculated by suggestions of Johnson et al., (1955).

\section{Results and Discussion}

In the present investigation, wider range of variability obtained between GCV and PCV for all the characters indicated that the traits were influenced by environmental factors also. The Analysis of variance showed significant difference among the genotypes for all the characters except the boll weight, lint index, elongation percentage and micronaire value (Table 1).

The PCV and GCV estimate explains the contribution of genetic and environmental components in the expression of phenotype. In the present investigation, PCV was higher than GCV explains that the observed variation was not only due to genotypes but also due to environment. The characters viz., number of bolls per plant $(39.63,51.99)$, number of flower bearing nodes $(30.65,39.52)$ and seed cotton yield $(27.36,44.1)$ expressed high GCV and PCV (Table 2).

These results explained that the genetic component contributed maximum to the phenotypic expression and the effect of environment was comparatively low. 
These results falls in line with Lokeshkumar et al., (2018), Joshi et al., (2018), Eswari et al., (2017), Devidas et al., (2017) for number of bolls per plant; Dhamayanathi et al., (2010) for number flower bearing nodes; Joshi et al., (2018), Aarthi et al., (2018), Lokeshkumar et al., (2018), Kumar et al., (2017), for seed cotton yield per plant.

Moderate GCV and PCV were recorded by Plant height $(12.97,15.18)$, number of sympodia per plant $(14.31,19.76)$, length of internode (14.35, 18.73), boll weight (14.32, 18.01), seed index $(10.03,10.94)$, lint index (14.46, 16.57), ginning out turn (10.73, 11.95), micronaire value $(11.06,15.08)$ (Table 2).

The results were in agreement with Lokeshkumar et al., (2018), Joshi et al., (2018), Khokhar et al., (2017) for plant height; Joshi et al., (2018), Aarthi et al., (2018) for number of sympodial branches; Aarthi et al., (2018), Khokhar et al., (2017), Eswari et al., (2017) for boll weight; Joshi et al., (2018), Abbas et al., (2015), Parmar et al., (2015) for seed index; Joshi et al., (2018), Aarthi et al., (2018), Khokhar et al., (2017) for lint index; Khokhar et al., (2017), Ahsan et al., (2015) for ginning out turn and Aarthi et al., (2018), Eswari et al., (2017), Abbas et al., (2015) for micronaire value.

Other characters such as days to first flowering $(8.85,8.92)$, days to fifty per cent flowering $(8.16,8.23)$, days to first boll bursting $(5.52,5.63)$, days to fifty per cent boll bursting $(6.32,6.42)$, upper half mean length $(6.0,6.82)$, uniformity index (1.03, $1.4)$, fibre strength $(4.4,5.44)$ and elongation per centage $(1.37,1.87)$ recorded low GCV and PCV (Table 2).

Devidas et al., (2017), kumar et al., (2017) registered similar results for days to first flowering; Aarthi et al., (2018), devidas et al.,
(2017) for days to fifty per cent flowering and Erande et al., (2014) for days to fifty per cent boll bursting. Low magnitude of both GCV and PCV was recorded by Joshi et al., (2018), Lokeshkumar et al., (2018), Shao et al., (2016) for upper half mean length; Lokeshkumar et al., (2018), Aarthi et al., (2018) were in line for uniformity index and elongation percentage, fibre strength.

The computations of heritability and genetic advance as percent of mean helps in selection of character for further breeding programme.

The characters such as Plant height, number of flower bearing node, boll weight, seed index and lint index, upper half mean length, ginning out turn, fibre strength expressed high heritability and therefore suggests that any selection in cotton based on the phenotypes of these characters will be effective.

Hence, improvement of these traits can be made through direct phenotypic selection. However, heritability estimates alone is not enough to produce a high genetic gain (Swarup et al., 2006).

Thus the traits like plant height, number of bolls per plant, number of flower bearing nodes, boll weight, lint index expressed high heritability estimates with high genetic advance as per cent of mean which indicates the reliability of additive gene action. Hence phenotypic selection will be effective in the improvement of these traits (Table 2).

The result of plant height in accordance with Joshi et al., (2018), Lokeshkumar et al., (2018); Preetha et al., (2007) for number of flower bearing node; Joshi et al., (2018), Lokeshkumar et al., (2018), Aarthi et al., (2018) for boll weight; Preetha et al., (2007) for number of flower bearing node, length of internode, length of sympodia; Joshi et al., (2018), Aarthi et al., (2018) for lint index. 
Table.1 ANOVA for yield, yield supporting and fibre quality characters

\begin{tabular}{|c|c|c|c|c|}
\hline S.no & $\begin{array}{l}\text { Character/source of } \\
\text { variation }\end{array}$ & Replication & Genotype & Error \\
\hline & & \multicolumn{3}{|c|}{ Mean sum of squares } \\
\hline 1 & Plant height $(\mathrm{cm})$ & 411.9 & $593.5^{* *}$ & 65.2 \\
\hline 2 & $\begin{array}{l}\text { Number of sympodial } \\
\text { branches }\end{array}$ & 8.547 & $18.73^{* *}$ & 4.35 \\
\hline 3 & Number of bolls & 185.6 & $217.3^{* *}$ & 42.1 \\
\hline 4 & $\begin{array}{l}\text { number of flower bearing } \\
\text { nodes }\end{array}$ & 1031.9 & $779.2^{* *}$ & 140.9 \\
\hline 5 & Length of internode (cm) & 0.06 & $1.64 *$ & 0.31 \\
\hline 6 & Length of sympodia (cm) & 85.82 & $105.68 * *$ & 22.51 \\
\hline 7 & Boll weight (g) & 0.52 & 0.99 & 0.16 \\
\hline 8 & Seed index & 0.32 & $2.37 * *$ & 0.14 \\
\hline 9 & Lint index & 0.04 & 1.24 & 0.12 \\
\hline 10 & Ginning out turn (\%) & 1.41 & $40.51^{* *}$ & 3.0 \\
\hline 11 & Days to first flowering & 30.94 & $51.16^{* *}$ & 0.27 \\
\hline 12 & $\begin{array}{l}\text { Days to fifty per cent } \\
\text { flowering }\end{array}$ & 38.25 & $53.62^{* *}$ & 0.32 \\
\hline 13 & Days to first boll bursting & 89.07 & $57.66^{* *}$ & 0.74 \\
\hline 14 & $\begin{array}{l}\text { Days to fifty per cent boll } \\
\text { bursting }\end{array}$ & 103.0 & $87.33^{* *}$ & 0.84 \\
\hline 15 & Upper half mean length & 0.57 & $8.95 * *$ & 0.79 \\
\hline 16 & Uniformity index & 0.22 & $2.78 * *$ & 0.61 \\
\hline 17 & Strength & 0.003 & $6.69 * *$ & 0.76 \\
\hline 18 & Elongation percentage & 0.012 & 0.02 & 0.01 \\
\hline 19 & $\begin{array}{l}\text { Micronaire } \\
(\mu \mathrm{g} / \text { inch })\end{array}$ & 2.8 & 0.94 & 0.21 \\
\hline 20 & Seed cotton yield (g) & 0.5 & $1130.3^{* *}$ & 393.0 \\
\hline
\end{tabular}

**-significance at $1 \%$ level

$*_{\text {-significance at } 5 \% \text { level }}$ 
Table.2 Genetic component of variance for yield, yield supporting and fibre quality parameters

\begin{tabular}{|c|c|c|c|c|c|}
\hline Character & Range & GCV & PCV & Heritability & $\begin{array}{l}\text { Genetic } \\
\text { advance as } \\
\text { percent of } \\
\text { mean }\end{array}$ \\
\hline Plant height(cm) & $\begin{array}{l}58.5- \\
135.6\end{array}$ & 12.97 & 15.18 & 72.98 & 22.82 \\
\hline Number of sympodia & $8.0-29.0$ & 14.31 & 19.76 & 52.44 & 21.35 \\
\hline Number of bolls & $5.0-59.0$ & 39.63 & 51.99 & 58.11 & 62.23 \\
\hline $\begin{array}{l}\text { Number of flower bearing } \\
\text { nodes }\end{array}$ & $17-105$ & 30.65 & 39.52 & 60.16 & 48.98 \\
\hline Length of internode(cm) & $2.5-7.1$ & 14.35 & 18.73 & 58.69 & 22.65 \\
\hline Length of sympodia (cm) & $\begin{array}{l}9.86- \\
43.5\end{array}$ & 19.76 & 26.6 & 55.19 & 30.24 \\
\hline Boll weight(g) & $\begin{array}{l}2.12- \\
5.65\end{array}$ & 14.32 & 18.01 & 63.22 & 23.46 \\
\hline Days to first flowering & $\begin{array}{l}6.52- \\
11.87\end{array}$ & 8.85 & 8.92 & 98.46 & 18.09 \\
\hline $\begin{array}{l}\text { Days to fifty percent } \\
\text { flowering }\end{array}$ & $\begin{array}{l}2.75- \\
7.82\end{array}$ & 8.16 & 8.23 & 98.22 & 16.65 \\
\hline Days to first boll bursting & $\begin{array}{l}22.57- \\
47.85\end{array}$ & 5.52 & 5.63 & 96.25 & 11.16 \\
\hline $\begin{array}{l}\text { Days to fifty percent boll } \\
\text { bursting }\end{array}$ & $39.9-61$ & 6.32 & 6.42 & 97.15 & 12.84 \\
\hline Seed index & $\begin{array}{l}44.65- \\
64\end{array}$ & 10.03 & 10.94 & 83.96 & 18.92 \\
\hline Lint index & $72.2-92$ & 14.46 & 16.57 & 76.09 & 25.98 \\
\hline Ginning out turn (\%) & $\begin{array}{l}75.84- \\
103\end{array}$ & 10.73 & 11.95 & 80.63 & 19.85 \\
\hline $\begin{array}{l}\text { Upper Half Mean } \\
\text { Length }(\mathbf{m m})\end{array}$ & $\begin{array}{l}23.1- \\
32.3\end{array}$ & 6.00 & 6.82 & 77.43 & 10.87 \\
\hline Uniformity index (\%) & $\begin{array}{l}79.6- \\
85.3\end{array}$ & 1.03 & 1.4 & 54.01 & 1.56 \\
\hline Fibre strength(g/tex) & $\begin{array}{l}24.3- \\
30.6\end{array}$ & 4.4 & 5.44 & 65.49 & 7.33 \\
\hline Elongation percent & $5.5-6.2$ & 1.37 & 1.87 & 53.14 & 2.05 \\
\hline Micronaire value( $\mu \mathrm{g} / \mathrm{inch})$ & $\begin{array}{l}2.67- \\
5.81\end{array}$ & 11.06 & 15.08 & 53.87 & 16.73 \\
\hline Seed cotton yield(g) & $\begin{array}{l}18.9- \\
232.44\end{array}$ & 27.36 & 44.1 & 38.48 & 34.95 \\
\hline
\end{tabular}


The characters number of sympodia per plant, number of bolls per plant, length of internode, length of sympodia and seed cotton yield exhibited moderate heritability and high genetic advance as per cent of mean.

Joshi et al., (2018), Aarthi et al., (2018) observed similar findings for number of sympodia; Kumar et al., (2017) for seed cotton yield; Joshi et al., (2018), Eswari et al., (2017) for number of bolls per plant.

The characters days to first flowering, days to fifty per cent flowering, days to first boll bursting, days to fifty per cent boll bursting, seed index, ginning out turn and upper half mean length registered high heritability and moderate genetic advance as per cent of mean. High heritability with moderate genetic advance as per cent of mean indicates that these traits were controlled by non-additive gene action and were improved by heterosis breeding.

Kumar et al., (2017), Shao et al., (2016) reported similar result for seed index; Joshi et al., (2018), Kumar et al., (2017) for ginning out turn and Lokeshkumar et al., (2018) for upper half mean length.

The characters uniformity index and elongation percentage observed moderate heritability and low genetic advance as per cent mean. Eswari et al., (2017) reported same result for uniformity index and Erande et al., (2014) recorded same result for elongation percentage.

High heritability and low genetic advance was observed by fibre strength. Khokhar et al., (2017), Shao et al., (2016) observed same result for fibre strength. Micronaire value recorded moderate values of heritability and genetic advance as percent of mean. It was on par with Eswari et al., (2017), Devidas et al., (2017).
Gene frequencies known to influence the magnitude of genotypic variance components. Since heritability depends upon such components, it may change because of change of gene frequencies brought about by selection.

The heritability depends upon the components of genotypic variance which known to be influenced by the gene frequencies and selection changes the gene frequencies and inturn changes the heritability.

From the present investigation it was concluded that the characters like plant height, boll weight, number of bolls per plant and seed cotton yield had ample scope for selection and genetic improvement.

\section{References}

Aarthi, V., AmalaBalu, P., and Premelatha, N. 2018. Genetic variability studies in germplasm of upland cotton (Gossypium hirsutum L.). Electronical Journal of Plant Breeding, 9(4), 1600-1605.

Abbas, H. G., Mahmood, A., and Ali, Q. 2015. Genetic variability and correlation analysis for various yield traits of cotton (Gossypium hirsutum L.). Journal of Agricultural Research, 53(4), 481-491.

Adsare Anil Devidas, Salve Abhay Narayanan, and Patil Narendrakumar Prakash. 2017. Study of genetic variability, heritability and genetic advance in some genotypes of Egyptian cotton (Gossypium barbadense L.).Journal of Global Sciences. 6(4), 49544957.

Adsare Anil, D., and Salve Abhay, N. 2017. Study on genetic variability for the quantitative traits in some genotypes of upland cotton (Gossypium hirsutum L.). Bioscience Discovery, 8(3), 365-368.

Ahsan, M. Z., Majidano, M. S., Bhutto, H., Soomro, A. W., Panhwar, F. H., Channa, A. R., and Sial, K. B. 2015. Genetic variability, coefficient of variance, heritability and genetic advance of some $\begin{array}{lll}\text { (Gossypium hirsutum } & \text { L.) }\end{array}$ 
accessions. Journal of Agricultural Science, 7(2), 147.

Burton, G. W. 1952. Quantitative inheritance in grasses. Pro VI IntGrassl Cong, 1952, 277283.

Dhamayanathi, K. P. M., Manickam, S., and Rathinavel, K. 2010. Genetic variability studies in Gossypium barbadense L. genotypes for seed cotton yield and its yield components. Electronic Journal of Plant Breeding, 1(4), 961-965.

Erande, C. S., Kalpande, H. V., Deosarkar, D. B., Chavan, S. K., Patil, V. S., Deshmukh, J. D., and Puttawar, M. R. 2014. Genetic variability, correlation and path analysis among different traits in desi cotton (Gossypium arboreum L.). African Journal of Agricultural Research, 9(29), 2278-2286.

Eswari, K. B., Sudheer Kumar, S., Gopinath and Rao, M. V. B. 2017. Genetic variability, Heritability and Genetic advance studies in cotton. International Journal of Developmental Research, 7(1), 1090210904.

Johnson, H. W., Robinson, H. F., and Comstock, R. 1955. Estimates of genetic and environmental variability in soybeans 1. Agronomy journal, 47(7), 314-318.

Khokhar, E. S., Shakeel, A., Maqbool, M. A., Anwar, M. W., Tanveer, Z., and Irfan, M. F. 2017. Genetic study of cotton (Gossypiumhirsutum L.) genotypes for different agronomic, Yield and quality traits. Pakistan Journal of Agricultural Research, 30(4), 363-372.

Lokeshkumar, B. M., and Patil, B. R. (2018). Estimation of Genetic Variability Parameters in $\mathrm{F}_{2}$ population of Gossypium hirsutum L. for Yield, Yield attributes and Fibre Quality Traits. International Journal of Current Microbiology and Applied Sciences, 7(9), 360-367.

Lush, J. L. 1940. Intra-sire correlations or regressions of offspring on dam as a method of estimating heritability of characteristics. Journal of Animal Science, 1940(1), 293-301.

Mohan Kumar, N. V., and Katageri, I. S. 2017. Genetic Variability and Heritability Study in $\mathrm{F}_{2}$ Population of Gossypium barbadense L. Cotton for Yield and its components. International Journal of Current Microbiology and Applied Sciences, 6(6), 975-983.

Panse, V. G., and Sukhatme, P. V. 1967. Statistical methods for agricultural workers 2nd edn. ICAR, New Delhi, 381pp.

Preetha, S., and Raveendran, T. S. 2007. Genetic variability and association analysis in three different morphological groups of cotton (Gossypium hirsutum L.). Asian Journal of plant sciences, 6(1), 122-128.

Shao, D., Wang, T., Zhang, H., Zhu, J. I. A. N. M. E. I., and Tang, F. 2016. Variation, heritability and association of yield, fibre and morphological traits in a near long staple upland cotton population. Pak. J. Bot, 48(5), 1945-1949.

Swarup, S., \& Chaugle, B. S. (1962). Studies on genetic variability in sorghum; phenotypic variation and heritable component in some quantitative characters contributing towards yield. Indian Journal of Genetics and Plant Breeding, 22, 31-36.

Vrindha Joshi and Patil, B. R. 2018. Genetic variability and heritability study in $\mathrm{F}_{2}$ population for yield, yield attributes and fibre quality traits in cotton (Gossypium hirsutum L.). Journal of Pharmacognosy and Phytochemistry, 7(4), 2816-2818.

\section{How to cite this article:}

Pandiyan, J., A. Ramalingam, M. Arumugam Pillai and Saravanan, S. 2019. Genetic Parameters of Economic and Fibre Characters in Upland Cotton (Gossypium hirsutum L.). Int.J.Curr.Microbiol.App.Sci. 8(06): 2084-2090. doi: https://doi.org/10.20546/ijcmas.2019.806.248 